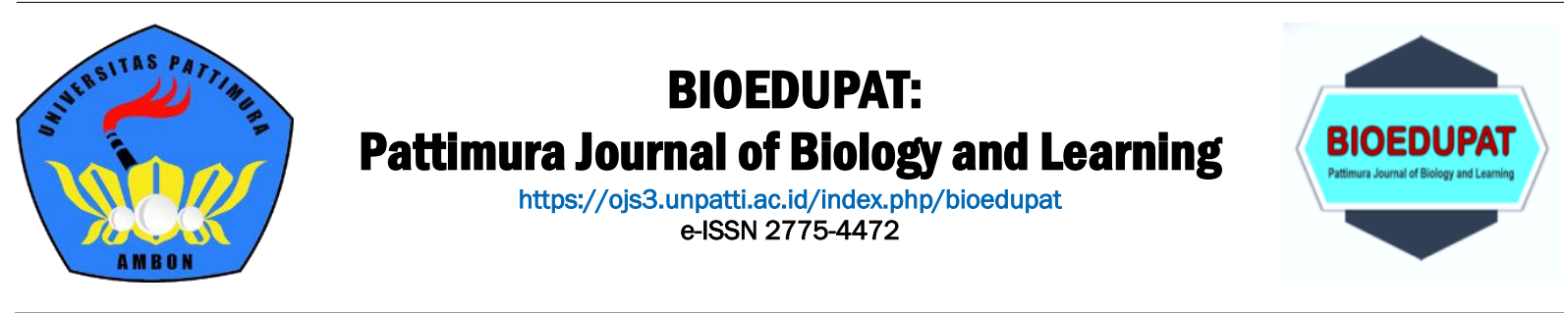

Research Article

\title{
Decreasing SGPT level and macrophage activity through CD68 expression in the Balb/c mice (Mus musculus) liver infected with Salmonella typhi after treating with atung seeds (Parinarium glaberimmun Hassk)
}

\author{
Eifan B. Pattiasina ${ }^{1,},{ }^{*}$ Pieter Kakisina ${ }^{2}$, Ferymon Mahulette $^{3}$ \\ ${ }^{1}$ Postgraduate Student of Biology Education, Pattimura University, \\ J. Dr. Tamaela, Ambon, Maluku 97114, Indonesia \\ 2 Department of Biology, Faculty of Mathematics and Natural Science, Pattimura University, \\ JI. Ir. M. Putuhena, Ambon, Maluku 97233, Indonesia \\ ${ }^{3}$ Study Program of Biology Education, Faculty of Teacher Training and Education, Pattimura University, \\ Jl. Ir. M. Putuhena, Ambon, Maluku 97233, Indonesia \\ *corresponding author: pattiasina2905@gmail.com
}

\begin{abstract}
Normally macrophages are always in the body and spread in various body tissues such as liver tissue (Kupffer cells). Macrophages in tissue can be identified by the expression of several markers, in humans the marker is CD68. The increase and decrease in macrophage activity in the liver can also be indicated by an increase in SGPT levels so that atung seeds have the ability to inhibit the growth of $S$. tyhpi bacteria which contain tannin compounds which can damage microbial cell walls and form bonds with microbial functional proteins so that bacterial growth is inhibited. The purpose of this study was to determine the SGPT levels and macrophage activity. The method used is laboratory experiment. The results showed an increase in SGPT levels in the positive control $(87.00 \pm 2,915)$ and a concentration of $25 \%(84.20 \pm 3,962)$ and a decrease in SGPT levels in the negative control $\left(50.80 \pm 2.168{ }^{*}\right), 50 \%$ concentration $\left(78.20 \pm 3.114{ }^{*}\right)$ and concentrations. $75 \%$ $(58.20 \pm 3,834)$, decreased macrophage activity in the liver also occurred at a concentration of $50 \%$ and at a concentration of $75 \%$, the liver was normal, which was indicated by the resulting brown expression.
\end{abstract}

Keywords: SGPT, Macrophage Activitty, CD68, Salmonella typhi, atung seeds

To cite this article:

Pattiasina, E. B., Kakisina, P., \& Mahulette, F. (2021). Decreasing SGPT level and macrophage activity through CD68expression in the Balb/c mice (Mus musculus) liver infected with Salmonella typhi after treating with atung seeds (Parinarium glaberimmun Hassk). Bioedupat: Pattimura Journal of Biology and Learning, Vol 1(1), 17-23. DOI: https://doi.org/10.30598/bioedupatv1i2pp17-23

\section{INTRODUCTION}

Infection-causing bacteria can usually be killed using drugs containing synthetic antibiotics. Therapy of infection with synthetic antibiotics can bring its own problems, namely the presence of bacterial resistance to these antibiotics and symptoms that indicate side effects with antibiotics. Efforts to find other SGPT alternatives in 
the treatment of infection are the use of traditional medicines derived from plants. The use of plant materials as medicine is because plants contain natural compounds that have the potential to be antibacterial, such as flavonoids, tannins, steroids, polyphenols, terpenoids, alkaloids, and saponins. Atung is a type of wild plant that is included in the Rosaceae tribe, is a megatherm plant and is very limited in the tropics. Atung is consumed as an additional ingredient in the preparation of raw fish-based dishes and also in rujak (salad) mixtures in Maluku. The atung plant is thought to be able to prevent diarrhea or stomach pain if you consume foods such as raw fish or salad (Sopaheluwakan, 2009). Atung seeds contain very high fatty oil, namely $42.68 \%$, and other contents, respectively, protein $(5.38 \%)$, crude fiber $(4.26 \%)$, ash $(2.14 \%)$, tannins $(1.65 \%)$, water $(8-13.15 \%)$, ethanol soluble components $95 \%(7.30 \%$ ) and components that are not detected around $23.20 \%$ (Adawiyah, 1998).

Tannins have antibacterial activity related to their ability to inactivate microbial cell adhesin as well as activate enzymes, and interfere with protein transport in the inner layer of cells (Cowan, 1999). Tannins also targeted polypeptides cell wall so that the formation of the cell walls becomes less perfect. This causes bacterial cells to become lysed due to osmotic and physical pressure so that the bacterial cells will die (Sari, 2011). The content of compounds in plants can trigger the system and can activate cellular components of the immune system, for example the function of phagocytosis without affecting humoral or cellular immunity (Tursinawati \& Dharmana 2015). People have started to choose traditional medicines to increase the immune system so that they are not susceptible to various diseases (Meyer et al., 2008).

Macrophages play an important role in an immune response, not only for innate immune response, but also for inducing adaptive immune response. Macrophages are phagocytes, which are the first known antigen presenting cells (APC). Macrophages and neutrophils are the first defense of the innate immune system against microbes and play an important role in bacterial phagocytosis (Samaranayake, 2012). Macrophages in tissue can be identified by the expression of several marker proteins, in humans the marker is CD68 (Nucera et al., 2010). CD68 is type I glycoprotein transmembrane mainly localized in the endosome compartment, due to its intracellular localization (Saito et al., 2003) and its characteristic structure (Holness et al., 1993). Macrophages can be found in circulation and in networks (Baratawidjaja \& Rengganis, 2010). Among the cytokines produced are interleukin-1 (IL-1) which is needed to stimulate the proliferation of T and B cells, fibroblasts and vascular endothelial growth factors which are needed to repair damaged tissue (Nah et al., 2008; Franca et al., 2010).

The destruction of cells causes changes in transport function and membrane permeability resulting in the release of the SGPT enzyme in the cytoplasm into the blood circulation. Alanine Aminotransferase (SGPT), is an enzyme found in liver cells and is effective in diagnosing hepatocellular destruction. SGPT enzymes are mostly found in the liver, so it is considered to be more specific to detect SGPT disease compared to AST (Sadikin, 2002). Tannin compounds in atung seeds are thought to reduce SGPT levels and macrophage activity through CD68 expression in the liver of $S$. typhi-infected mice. This requires a comprehensive research to prove it.

\section{METHODS}

\section{Research design}

This type of research is a laboratory experiment to determine the decrease in macrophage activity through the expression of CD68 in the liver of mice treated with steeping atung seeds. The design in this study was a completely randomized design (CRD). In this study, there were 3 treatments of concentrating the steeping of atung seeds, namely $25 \%, 50 \%$ and $75 \%$, as well as control, each treatment there were 5 replications of SGPT levels. The research design is shown in Table 1.

Table 1. Research design

\begin{tabular}{cccccc}
\hline \multirow{2}{*}{ Treatment } & \multicolumn{5}{c}{ Repetition } \\
\cline { 2 - 6 } & $\mathbf{1}$ & $\mathbf{2}$ & $\mathbf{3}$ & $\mathbf{4}$ & $\mathbf{5}$ \\
\hline Kontrol Positif (K') & K1 & K2 & K3 & K4 & K5 \\
Kontrol Negatif (K) & K1 & K2 & K3 & K4 & K5 \\
P1 & P 1.1 & P 1.2 & P 1.3 & P 1.4 & P 1.5 \\
P2 & P 2.1 & P 2.2 & P 2.3 & P 2.4 & P 2.5 \\
P3 & P 3.1 & P 3.2 & P 3.3 & P 3.4 & P 3.5 \\
\hline
\end{tabular}

The population in this study were Balb / c mice (Mus musculus), atung fruit seeds, Salmonella typhi. The samples in this study were male Balb / c mice, old atung fruit seeds, Salmoella typhi with a cell number of $3 \times 10^{8}$. 


\section{Preparation of Salmonella typhi bacterial suspension}

S. typhi bacteria that have been identified by gram staining, are rejuvenated first so that a culture age of 18-24 hours is obtained. Then the bacteria were suspended in physiological $\mathrm{NaCl}$ solution. The suspension density was adjusted according to the standard $1 \mathrm{Mc}$ solution. Farland corresponds to $3 \times 108$ cells / mL (Forbes et al., 2007).

\section{Observation of CD68 expression using immunohistochemistry}

- Observation of CD68 expression was carried out using immunohistochemical staining methods

- The liver histological preparations were washed with PBS (Phosphate Buffer Saline) pH7.4 for 3 minutes.

- Endogenous perioxide removal using 3\% $\mathrm{H} 2 \mathrm{O} 2$ for 20 minutes. Then the preparations were washed with PBS $\mathrm{pH} 7.4$ for 3 minutes, 3 times.

- Blocking, the preparation was dripped with primary CD68 antibody, then incubated at $4 \mathbb{} \mathrm{C}$ for one night. After that the preparations were washed with PBS pH 7.4 for 3 minutes, 3 times.

- The preparations were dropped with a secondary antibody labeled AP (Alkaline Phosphatase) 1: 2500 (anti IgG AP Labeled), incubated at room temperature for 60 minutes. After that the preparations were washed with PBS pH 7.4 for 3 minutes, 3 times.

- The preparations were dripped with SAN-HRP (Strep Avidin Horseradish Peroxidase) and incubated at room temperature for 60 minutes. After that the preparations were washed with PBS pH 7.4 for 3 minutes, 3 times.

- The application of chromogen by dripping 3,3-diaminobenzidine (DAB) solution, and incubating it at room temperature for 20 minutes, then washing it with distilled water for 5 minutes, 3 times.

- Counterstain uses hematoxylin. Incubated at room temperature for 20 minutes. Then drop the tap water, wash it with distilled water for 5 minutes 3 times.

- Dehydration was done with a solution of alcohol with a grade of $70 \%, 80 \%, 90 \%$ and $100 \%$ and absolute alcohol I and II for 1 minute each.

- Clearing was carried out with xylol I and xylol II each for 3 minutes, then the preparations were dried and aired

- Mounting using an entellant, then covered with a glass slide, labeled with the name of the preparation and then observed under a microscope

- If CD68 is detected, it will turn brown.

\section{SGPT level calculation}

SGPT levels were measured using a spectrophotometer (Shimadzu UV-1201 V). SGPT is determined based on enzymatic reactions. The serum is mixed with the reagent kit at a temperature of 25/30. 200 microliter of serum was taken and 1000 microliter of reagent kit. After homogeneity, read the absorbance at 1, 2, and 3 minutes using a spectrophotometer with a wavelength of $334 \mathrm{~nm}$. The results of the SGPT activity are expressed in units / liter $(\mathrm{U} / \mathrm{L})$ which is the number of enzymes in one liter of serum that can produce NAD + at the same time unit. SGPT levels using the formula: SGPT $(\mathrm{U} / \mathrm{L})=\triangle \mathrm{Abs}$. / Min $\times 1768$. SGPT level data were analyzed using ANOVA, while macrophage activity through CD68 expression in the liver of $S$. typhi infected mice after steeping atung seeds was analyzed descriptively.

\section{RESULTS AND DISCUSSION}

The results of SGPT levels in Balb / C mice (Mus musculus) infected with S.typhi after steeping atung seeds (Parinarium glaberimmum Hassk) showed that there was a decrease in SGPT levels. The test results can be seen in Table 2.

Tabel 2. Average SGPT Levels after Steeping Atung Seed (Parinarium glaberimmmum Hassk) in Balb / C Mice (Mus musculus)

\begin{tabular}{cc}
\hline Treatment & Average SGPT Level (U/L) \\
\hline Kontrol (-) & $50.80 \pm 2.168^{\mathrm{a}}$ \\
Kontrol (+) & $87.00 \pm 2.915^{\mathrm{d}}$ \\
Levels 25\% & $84.20 \pm 3.962^{\mathrm{d}}$ \\
Levels 50\% & $78.20 \pm 3.114^{\mathrm{b}}$ \\
Levels $75 \%$ & $58.20 \pm 3.834^{\mathrm{c}}$ \\
\hline
\end{tabular}

Note: Superscript the same letter shows no significant difference in the level of confidence $95 \%(p<0,05)$.

The Duncan test results on the average SGPT level in mice showed that there were differences in each treatment group, this was indicated by the giving of an asterisk to the average value. In the negative group it was 
different from the positive control, treatment levels were $25 \%, 50 \%$ and $75 \%$. The positive control has a difference with the treatment concentration of $50 \%$ and $75 \%$, while for the $25 \%$ level treatment has no difference with the positive control. This is because the results of the average SGPT level and standard deviation in the Duncan test, positive control with $25 \%$ level treatment, showed no difference.

Table 1 shows the average SGPT level in the negative group with an average SGPT level of $50.80 \mathrm{U} / \mathrm{L}$. This value is used as a reference to see the difference in each treatment because the negative control is not treated. In the positive control, the average SGPT level was $87.00 \mathrm{U} / \mathrm{L}$. This value is greater than negative control. The positive group of mice was induced by Salmoella typhi which could damage the liver cells of the mice, causing a high average SGPT level.

At a concentration of $25 \%$, the average SGPT level is $84.20 \mathrm{U} / \mathrm{L}$. When compared with positive controls, the average SGPT value was still high. At a concentration of $50 \%$, it showed an average SGPT level of $78.20 \mathrm{U} / \mathrm{L}$ and experienced a significant decrease when compared to the positive control and the level of $25 \%$. The result of SGPT levels at $75 \%$ is a concentration that has an average SGPT level of $58.20 \mathrm{U} / \mathrm{L}$ which indicates that at $75 \%$ levels of liver cells are in a normal state with a significant decrease in SGPT levels when compared to negative controls which are the inner group normal condition (no treatment).

From the measurement results of SGPT levels, histopathological observations were made of macrophage activity through the expression of CD68. The results of macrophage activity through CD68 expression can be seen in Figure 1.
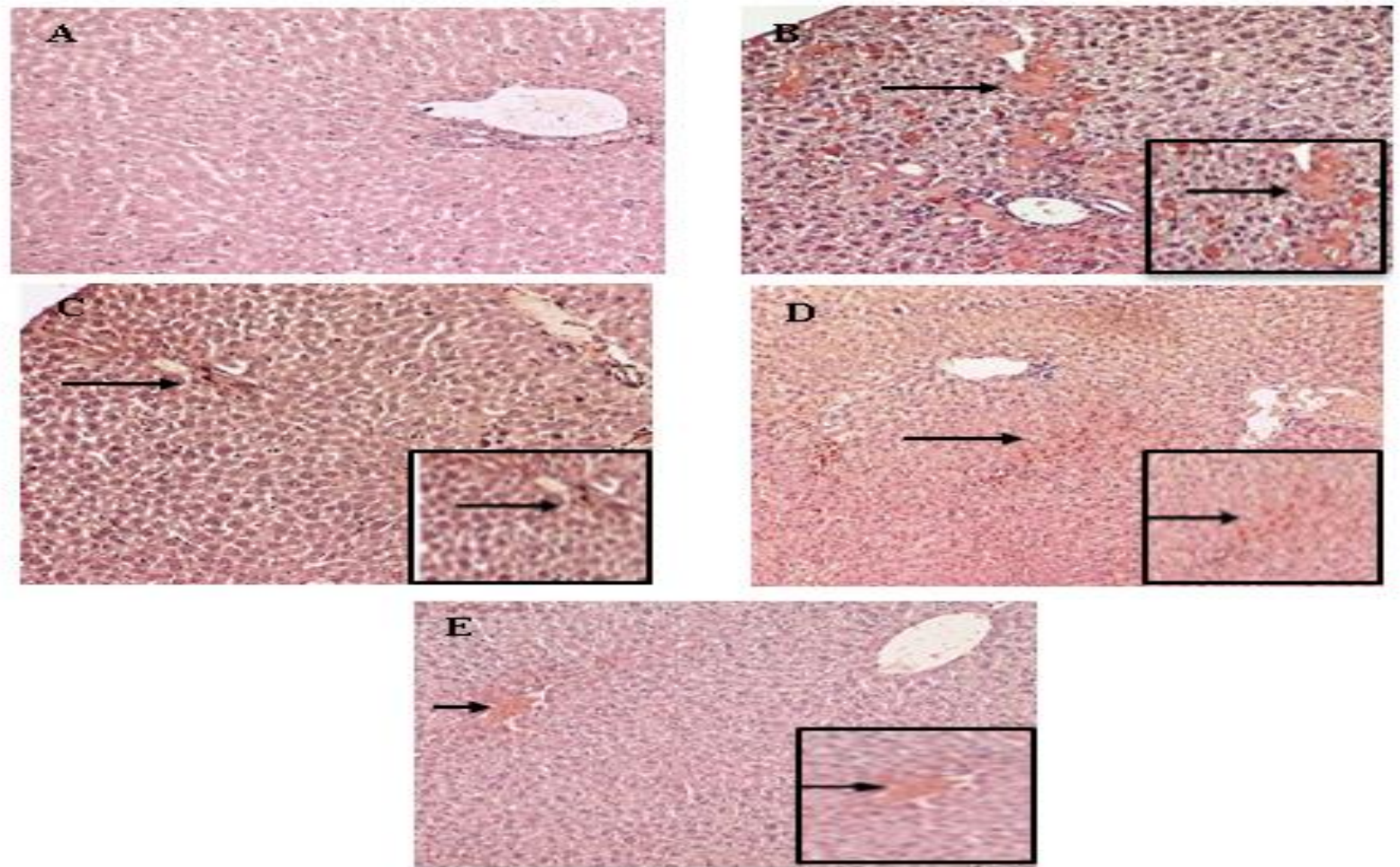

Figure 1. Macrophage activity through CD68 expression in the liver of Balb / $C$ mice infected with Salmonella tphi after steeping atung seeds. Negative control (A), positive control (B), concentration $25 \%(C)$, concentration $50 \%$ (D), concentration $75 \%$ (D). The staining was carried out using the indirect immunohistochemical method showing that cells expressing CD68 were shown as brown cells observed under a light microscope with a magnification of 1000x. The preparations were ligated with CD68 monoclonal antibody, a secondary antibody labeled peroxidase, then characterized by double staining using DAB and hematoxylin eosin. The arrows indicate macrophage activity.

Figure 1 shows the activity of macrophages through CD68 expression in the liver of mice infected with Salmonella typhi after steeping atung seeds which shows that the activity of macrophages expressed through CD68 is marked in brown in histopathology, namely the activity of macrophages increases in the phagocytosis process when a lot of brown color is produced. and there is a decrease in macrophage activity if the brown color is low. Serum Glutamic Pyruvic Transaminase (SGPT) is the main enzyme found in liver cells and is effective in diagnosing hepatocellular destruction (Kee \& Lefever, 2014). SGPT normal levels are expressed in the U / L 
range and will increase if there is liver damage (Kosasih, 2008). SGPT levels will increase due to Salmonella typhi and produce endotoxins and will multiply and attack liver tissue resulting in an increase in SGPT levels (Widyastuti, 2016).

The results showed that the average SGPT levels in mice infected with S. typhi after steeping atung seeds with a concentration of $75 \%$ contained secondary metabolites, namely tannins with high concentrations so that the SGPT level decreased, namely the average SGPT level was $58.20 \mathrm{U} / \mathrm{L}$ with standard deviation 3,834, when compared with the $S$. typhi infected group of mice after being treated with steeping atung seeds with a concentration of $25 \%$ had an average SGPT level of $84.20 \mathrm{U} / \mathrm{L}$ with a standard deviation of 3,962 and a concentration of $50 \%$ with an average value of SGPT levels $78.20 \mathrm{U} / \mathrm{L}$ with a standard deviation of 3.114 . The decrease in SGPT levels in the liver of S. typhi-infected mice (Mus musculus) was treated with the infusion of atung seeds (Parinarium glaberimmum Hassk) with a concentration of $75 \%$ lower than the concentrations of $25 \%$ and $50 \%$. It is assumed that the tannin content in the infusion of atung seeds with a high concentration of $75 \%$ so that the ability to inhibit the growth of S. typhi is better than the concentrations of $25 \%$ and $50 \%$. The results of this study indicated that there was a decrease in the levels of SGPT in mice (Mus musculus) infected with S. typhi treated with $25 \%$ to $75 \%$ concentration of atung seeds, so it can be said that the decrease in SGPT levels was in line with the increase in the concentration of atung seed steeping (Parinarium glaberimmum Hassk). This opinion is in accordance with Lee et al. (2013) which states that tannins in low concentrations are not able to inhibit bacterial growth, whereas at high concentrations tannins work by forming stable bonds with bacterial proteins so that the bacterial protoplasm is coagulated. Furthermore, Sari (2011) stated that besides that tannins also have a target on cell wall polypeptides so that the formation of the cell walls becomes less than perfect. Because lysis occurs in the bacterial cell wall, it causes osmotic and physical pressure so that the bacterial cell will die.

The S. typhi infection given will stimulate macrophages to activate and move to the source of infection. The lipopolysaccharide content in the cell walls of $S$. typhi is a signal for macrophages to activate. Macrophage activation has a high ability to carry out phagocytosis. These cells will destroy all foreign bodies such as germs, damaged cells, tumor cells, colloid objects, and large molecules (Chanana et al., 2007). Normally macrophages are always in the body and scattered in various body tissues such as lungs (alveolar macrophages), liver tissue (Kupffer cells), joint spaces (synovial cells type A), central nervous system (Schwann cells or microglia), space serous (pleural and peritoneal macrophages), binding tissue (histiocytes). Macrophages in tissue can be identified by the expression of several markers, one of which is CD68 (Nucera et al., 2010).

CD68 in the liver of mice (Mus musculus) infected with S. typhi after steeping atung seeds (Parinarium glaberimmum Hassk) can be seen in Figure 1. Histopathological preparations of the mice's liver can be seen from the activity of macrophages using the immunohistochemical method. Immunohistochemistry is a method of staining the substance or active ingredient in tissues using the basic principles of immunology, namely the binding of the active ingredient (antigen) to a specific active site by an anti-active ingredient (antibody). The results of the antigen and antibody reactions can be identified in the specimen when the antibody is bound by a marker.

The results showed that the histopathological preparations of the mice's liver could be seen the presence of macrophage activity using the immunohistochemical method through the expression of CD68. The presence of macrophage activity in the histopathological liver tissue of mice can be visualized with a brownish color. The brown color is the result of the interaction between the antigen that binds to the primary antibody (110kDA and CD68) and the secondary antibody in the form of Strep Avidin horseradish peroxidase (SA-HRP) and the diamino benzidine (DAB) substrate. Chromogen DAB (3,3- diaminobenzidine tetrahydrocloride) contains $\mathrm{H}_{2} \mathrm{O}_{2}$ peroxide as a marker substance that will form a complex with the peroxidase enzyme in the SA-HRP complex (Strepvidin horseradish peroxidase). The complex formed from DAB chromogen will form a dark brown color. This chromogen has a very strong bond with peroxide so that the dehydration and clearing processes will not change color.

In the negative control group, CD68 in the liver of mice was not expressed, this was because the negative control group was the untreated group so that there was no interaction between the antigen that binds to the primary antibody (110kDA and CD68) and the secondary antibody in the form of Strep Avidin horseradish peroxidase (SA- HRP) as well as the diamino benzidine (DAB) substrate. In the positive control group of mice infected with $\mathrm{S}$. typhi after steeping atung seeds showed that CD68 in the liver of the expressed mice were marked with a brown color, this was due to the interaction between antigens that bind to primary antibodies (110kDA and CD68) and secondary antibodies. in the form of Strep Avidin horseradish peroxidase (SA-HRP) and diamino benzidine (DAB) substrate. The identification of macrophage activity in the liver histology of mice showed a bond between antigen and primary antibody visualized with brownish color on the hepatocytes and synocytes. 
The positive control mice infected with S. typhi and not treated with steeping atung seeds showed CD68 in the liver of the expressed mice which was marked by a brown color which was produced a lot when compared to the S.typhi infected group after steeping atung seeds with a concentration of $25 \%, 50 \%$ and $75 \%$. This is because CD68 can be significantly regulated in macrophages that respond to inflammatory stimuli (O'Reilly et al., 2003; O'Reilly et al., 2007) and CD68 as a myeloid-specific marker, which is expressed in abundance by macrophages. (Betjes et al., 1991). In addition, CD68 is also used as a histochemical / cytochemical marker of inflammation associated with monocyte / macrophage involvement (Ferenbach, 2008). CD68 is also used to identify cells from macrophage lineages such as histiocyte tissue, Kupffer cells, and osteoclasts (Brooks et al., 2009). Several studies have demonstrated a significant upregulation of CD68 expression in macrophages in response to inflammatory stimuli such as exposure to oxLDL (Ramprasad et al., 1996; Yoshida et al., 1998; Tsukamoto et al., 2002) and chronic stimulation with bacterial lipopolysaccharide (LPS) or inflammatory cytokine interferon y (IFNү).

The activity of macrophages in the infusion of atung seeds with a concentration of $25 \%$ increased, it is thought that the tannin content was in low concentrations so that it was not able to inhibit $S$. typhi, when compared with concentrations of $50 \%$ and $75 \%$. Whereas for the $50 \%$ concentration there was a decrease in macrophage activity when compared to the $25 \%$ concentration. At a concentration of $75 \%$ there was a decrease in the activity of macrophages which was marked by CD68 in the liver of the mice which was expressed to produce a small amount of brown color, this indicated that the tannin content was at a concentration of $75 \%$ in large quantities so that the tannin content in atung seeds had the ability to inhibit the growth of $S$. typhi and can damage microbial cell walls and form bonds with microbial functional proteins and cause inhibited bacterial growth (Sudira et al., 2011).

\section{CONCLUSION}

From the results of the research conducted, it can be concluded that the infusion of atung seeds (Parinarium glaberimmum Hask) with a concentration of $75 \%$ was able to reduce SGPT levels in mice (Mus musculus) infected with S. typhi after steeping atung seeds (Parinarium glaberimmum Hassk) when compared with a concentration of $25 \%$ and $50 \%$. Steeping atung seeds (Parinarium glaberimmum Hask) with a concentration of $75 \%$ was able to reduce the activity of macrophages through the expression of CD68 in the liver of mice (Mus musculus) infected with $S$. typhi after being treated with the infusion of atung seeds (Parinarium glaberimmum Hask) which is characterized by a brown color produced less when compared with concentrations of $25 \%$ and $50 \%$.

\section{REFERENCES}

Adawiyah, D. R. (1998). Studi pengembangan metode ekstraksi komponen antimikroba biji buah atung (Parinarium glaberrimum Hassk) [Study on the development of antimicrobial component extraction methods of atung fruit seeds (Parinarium glaberrimum Hassk)]. S2 thesis. PPs. IPB: Bogor. (In Indonesian)

Baratawidjaja, K. G., \& Rengganis, I. (2010). Imunologi Dasar [Basic Immunology]. 9th ed. BP FKUI, Jakarta:. (In Indonesian)

Betjes, M. G., Haks, M. C., \& Tuk, C. W. (1991). Monoclonal antibody EBM11 (anti-CD68) discriminates between dendritic cells and macrophages after short-term culture. Immunobiology, 183, 79-87. doi: https://doi.org/10.1016/S0171-2985(11)80187-7

Brooks, E., Simmons-Arnold, L., \& Naud, S. (2009). Multinucleated giant cells' incidence, immune markers, and significance: a study of 172 cases of papillary thyroid carcinoma. Head and Neck Pathology, 3, 95-99. doi: https://doi.org/10.1007/s12105-009-0110-9

Chanana, V., Ray, P., Rishi, D. B., \& Rishi, P. (2007). Reactive nitrogen intermediates and monokines induce caspase-3 mediated macrophage apoptosis by anaerobically stressed Salmonella typhi. Clinical \& Experimental Immunology. 150(2): 368-374. doi: https://doi.org/10.1111/j.1365-2249.2007.03503.x

Cowan, M. M. (1999). Plant products as antimicrobial agents. Clinical Microbiology Reviews, 12, 564-582.

Ferenbach, D., \& Hughes, J. (2008). Macrophages and dendritic cells: what is the difference?. Kidney International, 74, 5-7. doi: https://doi.org/10.1038/ki.2008.189

Forbes, B. A., Sahm, D. F., \& Weissfeld, A. S. (2007). Bailey and Scott's Diagnostic Microbiology. $12^{\text {th }}$ ed. Missouri: Mosby.

Franca, A. C. H., Eduardo, L. F., Joanna, C. M., Valeria, C. C., Uender, C. R. P., \& Claudemir, B. (2010) Immunomodulatory effects of herbal plants plus melatonin on human blood phagocytes. International Journal of Phytomedicine, 2, 354-62. doi: https://doi.org/10.5138/ijpm.2010.0975.0185.02050 
Holness, C. L., da Silva, R. P., Fawcett, J., Gordon, S., \& Simmons, D. L. (1993). Mac-rosialin, a mouse macrophage-restricted glycoprotein, is a member of the lamp/Igp family. Journal of Biological Chemistry, 268, 961-966.

Kee., \& Lefever, J. (2014). Pedoman pemeriksaan laboratorium dan diagnostik [Laboratory and Diagnostic Examination Guidelines]. Edition 6. EGC, Jakarta.

Kosasih, E. N., \& Kosasih, A. S. (2008). Tafsiran hasil pemeriksaan laboratorium klinik [Interpretation of Clinical Laboratory Examination Results]. Karisma Publishing Group, Tangerang.

Lee, J. H., Park, J. H., Cho, H. S., Joo, S. W., Cho, M. H., \& Lee, J. (2013). Anti-biofilm activities of quercetin and tannic acid against Staphylococcus aureus. Biofouling, 29(5), 491-499.

Meyer, S. L. F., Lakshman, D. K., Zasada, I. A., Vinyard, B. T., \& Chitwod, D. J. (2008). Dose response effects of clove oil from Syzygium aromaticum on the root-knot nematode Meloidogye incognita. Pest Management Science, 64, 223-229. doi: https://doi.org/10.1002/ps.1502

Nah, S. S., Choi, I. Y., Lee, C. K., Oh, J. S., Kim, Y. G., Moon, H. B., \& Yoo. (2008). Effects of advanced glycation and products on the expression of COX2, PGE2 and no in human osteoarthritic chondrocytes. The Journal of Rheumatology, 47, 425-431. doi: https://doi.org/10.1093/rheumatology/kem376

Nucera, S., Biziato, D., \& Palma, M. D. (2010). The interplay between macrophages and angiogenesis in development tissue injury and regeneration. The International Journal of Developmental Biology, 55, 495503. doi: https://doi.org/10.1387/ijdb.103227sn

O'Reilly, D., \& Greaves, D. R. 2007. Cell-type-specific expression of the human CD68 gene is associated with changes in Pol II phosphorylation and short-range intrachromosomal gene looping. Genomics, 90: 407-415. doi: https://doi.org/10.1016/j.ygeno.2007.04.010

O'Reilly, D., Quinn, C. M., \& El-Shanawany, T. (2003). Multiple ets factors and interferon regulatory factor-4 modulate CD68 expression in a cell type-specific manner. Journal of Biological Chemistry, 278, 2190921919. doi: https://doi.org/10.1074/jbc.M212150200.

Ramprasad, M. P., Terpstra, V., \& Kondratenko, N. (1996). Cell surface expression of mouse macrosialin and human CD68 and their role as macrophage receptors for oxidized low density lipoprotein. Proceedings of the National Academy of Sciences, 93, 14833-14838. doi: https://doi.org/10.1073/pnas.93.25.14833

Sadikin, M. (2002). Biokimia enzim [Enzyme biochemistry]. Widya medika, Jakarta. (In Indonesian).

Saito, G., Swanson, J. A., \& Lee, K. D. (2003). Drug delivery strategy utilizing conjugation via reversible disulfide linkages: role and site of cellular reducing activities. Advanced drug delivery reviews, 55(2), 199-215.

Samaranayake, L. 2012. Essential Microbiology for Dentistry. $4^{\text {rd }}$ ed. Elsevier, Hongkong. pp. 100-115.

Sari, F. P., Sari, S. M. (2011). Ekstraksi zat aktif antimikroba dari tanaman yodium (Jatropha multifida Linn) sebagai bahan baku alternatif antibiotik alami [Extraction of antimicrobial active substances from iodine plants (Jatropha multifida Linn) as alternative raw materials for natural antibiotics]. Fakultas Teknik Universitas Diponegoro: Semarang. (In Indonesian).

Sudira, I. W., Merdana, I., \& Wibawa, I. (2011). Uji daya hambat ekstrak daun kedondong (Lannea grandis Engl) terhadap pertumbuhan bakteri erwinia carotovora [Inhibition test of kedondong leaf extract (Lannea grandis Engl) on the growth of the bacteria Erwinia carotovora]. Buletin Veteriner Udayana, 3(1), 45-50. (In Indonesian).

Tursinawati, Y., \& Dharmana, E. (2015). Efektivitas pemberian kombinasi produk herbal antibiotik terhadap infeksi Salmonella typhimurium pada mencit Balb/c. University Research Coloquium, (2), 231-237.

Tsukamoto, K., Kinoshita, M., \& Kojima, K. (2002). Synergically increased expression of CD36, CLA-1 and CD68, but not of SR-A and LOX-1, with the progression to foam cells from macrophages. Journal of Atherosclerosis and Thrombosis, 9, 57-64. doi: https://doi.org/10.5551/jat.9.57

Widyastuti, R. (2016). Hubungan kadar SGPT (Serum Glutamic Pyruvic Transminase) dengan titer widal antigen O Salmonella tyhpi pada penderita demam typhoid [Relationship between SGPT (Serum Glutamic Pyruvic Transminase) levels with Salmonella tyhpi widal antigen $O$ titer in typhoid fever patients]. The Journal of Muhammadiyah Laboratory Technologist, 2(1), 43- 53. (In Indonesian).

Yoshida, H., Quehenberger, O., \& Kondratenko, N. (1998). Minimally oxidized low-density lipoprotein increases expression of scavenger receptor $\mathrm{A}, \mathrm{CD} 36$, and macrosialin in resident mouse peritoneal macrophages. Arteriosclerosis, Thrombosis, and Vascular Biology, 18, 794-802. doi: https://doi.org/10.1161/01.atv.18.5.794 